RESEARCH ARTICLE

\title{
EFFECT OF DIETARY PROBIOTIC SUPPLEMENTATION ON GROWTH, SURVIVAL, COLORATION AND STRESS RESISTANCE IN GUPPY (Poecilia reticulata Peters, 1859)
}

\author{
Samarawardane T, Radampola $\mathrm{K}^{*}$ and Rathnapala S \\ Department of Fisheries and Aquaculture, Faculty of Fisheries \& Marine Sciences \& Technology, \\ University of Ruhuna, Matara, Sri Lanka
}

Received: 2021.06.18, Accepted: 2021.07.30

\begin{abstract}
Effect of commercial probiotic (AQUALACTTM) on the growth performance, feed utilization, colouration and stress resistance of Poecilia reticulata was investigated. Experimental diets were iso nitorgenic (30\% Protein) and probiotic mixture (PM) was added in four different levels by replacing wheat flour. The diets were labeled as 0PM $(0 \%), 50 P M(0.5 \%), 75 P M(0.75 \%)$ and 100PM $(1.0 \%)$. Male guppy fry $(28$ days; $0.11 \pm 0.01 \mathrm{~g}$ and $2.20 \pm 0.05 \mathrm{~cm})$ were fed ad libitum twice daily and growth performance and feed efficiency were evaluated. After 42 days of the feeding trial, guppies were exposed to $\mathrm{NaCl}$ salinity $\left(35 \mathrm{gL}^{-1}\right)$ stress test. All dietary probiotic supplemented diets significantly influenced the growth performance, colouration and salinity stress resistance of fish compared to 0PM diet. Fish in 75PM treatment showed significantly highest growth (total length $-3.35 \pm 0.01 \mathrm{~cm}$; weight- $0.43 \pm$ $0.01 \mathrm{~g})$ and better feed conversion ratio $(2.51+0.01)$. The study revealed that $0.75 \mathrm{~g} / 100 \mathrm{~g}$ probiotic level was the best level among the tested levels to enhance the growth performance, colouration and salinity stress resistance of Guppy in aquarium conditions.
\end{abstract}

Keywords: AQUALACTTM mixture, Ornamental fish, Growth performance, Colouration, Salinity stress

\section{INTRODUCTION}

Probiotics can be defined as beneficial microorganisms or their products that provide health benefits to the hosts (Fuller 1989). Probiotics are used in aquaculture to improve growth performance, reduce diseases and develop the immune system of cultured organisms (Verschuere et al. 2000). Currently, the most common probiotics used in aquaculture are Bacillus, Lactobacillus sp., Enterococcus sp., Carnobacterium and yeast which are administered by enrichment of live foods, added to the diet or the culture water as in powder or liquid form (Doan et al. 2020). The use of probiotics as growth promoters in edible fish (Nile tilapia- Haroun et al. 2006), ornamental fish (Swordtail and Guppy- Ghosh et al. 2008; Dharmaraj and Dhevendaran 2010) and in shellfish culture (Immanuel et al. 2004) has been reported.

\footnotetext{
*Corresponding author: kumudu@fish.ruh.ac.lk
}

Dietary probiotics influenced the immune response, especially at the early stage of gilthead sea bream (Picchietti et al. 2007) and improved fish growth, health and feed digestibility in rainbow trout (Nikoskelainen et al. 2001). In ornamental fish culture, the use of probiotic bacteria to enhance the growth performance of cultured species and to improve the quality of water in which fish are cultured has been reported (Ghosh et al. 2008; Hernandez et al. 2010). Dharmaraj and Devendran (2010) reported that Streptomyces isolated from marine sponges could promote the growth of ornamental fish, Red Swordtail (Xiphophorus helleri). Anuar et al. (2017) described that probiotics are used not only to enhance growth and immunity but also for sharpening the colour of aquarium fish.

Several commercial preparations of probiotics which contain live microorganisms have been introduced to enhance the productivity of 
aquaculture operations. Probiotics can be used as a food additive added directly to the culture tank or mixed with food (Cruz et al. 2012). AQUALACTTM is a commercially available multi-strain probiotic, consisting of four bacterial species including Lactobacillus sporogenes, Lactobacillus acidophilus, Bacillus subtilis and Bacillus licheniformis and one species of yeasts (Saccharomyces cervisiae) with seaweed extract, which is used in feed formulation for fish and shrimps. In Sri Lanka, a commercial probiotics mixture, AQUALACTTM is used in the shrimp farming industry, but not used in other fish farming practices (personal communication-KMN Aqua Services (PVT) Ltd). The use of probiotics as an environmentally friendly alternative is increasing in the aquaculture industry (Cruz et al. 2012).

Guppy is a commercially important ornamental freshwater fish species, and contributed to 60$70 \%$ of the total exported ornamental fish production in Sri Lanka and also has high demand in the local market (EDB 2021). Though guppy culture is popular as a small scale enterprise among ornamental fish farmers in Sri Lanka, farmers are mainly dependent on the imported fish feeds to feed their fish. Therefore, the present study was undertaken to develop fish feeds by incorporating probiotics and to determine the effect of dietary supplementation of commercial probiotics AQUALACTTM mixture on growth performance, nutrient utilization in colouration and stress resistance of guppy.

\section{MATERIALS AND METHODS}

Twenty-eight days old 144 male guppy (Poecilia reticulata) fry (Red Blonde variety) were purchased from an ornamental farm at Karandeniya and kept in fibreglass tanks for two days for acclimatization. Then fish (2.24 \pm $0.03 \mathrm{~cm}$ and $0.11 \pm 0.01 \mathrm{~g}$ ) were stocked at a stocking density of 12 fish per tank in twelve glass tanks $(60 \times 30 \times 30 \mathrm{~cm} ; 20 \mathrm{~L})$. Tanks were maintained under natural photoperiod $(12 \mathrm{~h}$ light: $12 \mathrm{~h}$ dark) and continuous aeration was supplied to all tanks. Water quality parameters were monitored throughout the experimental period.

\section{Source of probiotics}

A dietary probiotic mixture, AQUALACTTM (Biostadt India Ltd, Mumbai, India) was obtained from KMN Aqua Services (PVT) Ltd, Sri Lanka. AQUALACTTM is a commercially available multi-strain probiotic, consisting of four bacterial species and one species of yeasts with seaweed extract (Table 1) which is used in feed formulation for fish and shrimps.

\section{Diet preparation and feeding}

The feed ingredients were finely ground before preparing the feed. All ingredients were mixed thoroughly and fish oil was gradually added thereafter. During mixing, 10 - $15 \%$ water was added to obtain smooth dough which was then steam cooked for 30 min and allowed to cool. The control diet which has no probiotic supplement $(0 \%)$ was pelletized and the pellets $(3 \mathrm{~mm})$ were airdried and stored in dry airtight containers at $28{ }^{\circ} \mathrm{C}$. Other three diets in which the dietary probiotics mixture AQUALACTTM (PM) was incorporated to the cooled dough (already steam cooked) at three different

Table 1: Types of microorganisms and other ingredients exist in the AQUALACTTM probiotic per Kg (based on the producer's protocol)

\begin{tabular}{ll}
\hline $\begin{array}{l}\text { Types of microorganisms } \\
\text { and other ingredients }\end{array}$ & Amount \\
\hline $\begin{array}{l}\text { Bacteria species } \\
\text { Lactobacillus sporogenes }\end{array}$ & $45,000 \mathrm{mil} \mathrm{cfu}$ \\
Lactobacillus acidophilus & $45,000 \mathrm{mil} \mathrm{cfu}$ \\
Bacillus subtilis & $45,000 \mathrm{mil} \mathrm{cfu}$ \\
Bacillus licheniformis & $45,000 \mathrm{mil} \mathrm{cfu}$ \\
\hline Fungi species & \\
$\quad$ Saccharomyces cervisiae & $45,000 \mathrm{mil} \mathrm{cfu}$ \\
\hline Seaweed extract & $100 \mathrm{~g}$ \\
\hline Enzyme complex contains & \\
Amylase & $24,000 \mathrm{IU}$ \\
Phytase & $22,00,000 \mathrm{IU}$ \\
Protease & $400,00,000 \mathrm{IU}$ \\
Cellulase & $150-250 \mathrm{IU}$ \\
Beta-galactosidase & $800-1000 \mathrm{IU}$ \\
Lipase & $50-100 \mathrm{IU}$ \\
\hline
\end{tabular}


Table 2: Ingredient composition (g/100g) of the experimental diets. (0PM- no probiotic; 50PM-0.5 \% probiotic mix; 75PM- 0.75\% probiotic mix; 100PM$1 \%$ probiotic mix)

\begin{tabular}{|c|c|c|c|c|}
\hline \multirow[t]{2}{*}{ Ingredient (g) } & \multicolumn{4}{|c|}{ Experimental diets } \\
\hline & OPM & 50PM & 75PM & 100PM \\
\hline Fish meal & 25 & 25 & 25 & 25 \\
\hline Soybean meal & 24 & 24 & 24 & 24 \\
\hline Coconut meal & 20 & 20 & 20 & 20 \\
\hline Wheat flour & 14 & 13.5 & 13.25 & 13 \\
\hline Rice bran & 11 & 11 & 11 & 11 \\
\hline Vit. \& Mineral mix* & 3 & 3 & 3 & 3 \\
\hline Fish oil & 3 & 3 & 3 & 3 \\
\hline Probiotic mix & 0 & 0.5 & 0.75 & 1 \\
\hline \multicolumn{5}{|c|}{ Proximate composition } \\
\hline Moisture & 7.26 & 7.54 & 7.13 & 7.29 \\
\hline Ash & 9.15 & 9.14 & 9.11 & 9.12 \\
\hline Crude lipid & 7.97 & 7.87 & 7.94 & 7.91 \\
\hline Crude protein & 31.65 & 31.59 & 31.55 & 31.50 \\
\hline
\end{tabular}

* Commercial vitamin and mineral mixture

concentrations i.e. $0.5 \%$ (50PM), $0.75 \%$ (75PM), $1.0 \%(100 \mathrm{PM})$ respectively (Table $2)$. Then the pellets were extruded, dried and stored in dry airtight containers at $28{ }^{\circ} \mathrm{C}$.

All fish were fed twice daily, at 08:00am and 16:00pm up to satiation (ad libitum) using the respective diet for 42 days. The chemical composition of the feed ingredients and the experimental diets were analyzed following the methods described in AOAC (1990).

\section{Growth performance and feed utilization}

Total body weight $(\mathrm{g})$ and total length $(\mathrm{cm})$ of fry were measured individually at the beginning and fortnight intervals during 42 day period. Growth performance indicators i.e. average daily gain (\% ADG -eqn 1$)$ and specific growth rate (\% SGR -eqn 2) and survival rate (eqn 3 ) were calculated according to the standard formula (Ricker 1979). Condition factor (K) (eqn 4) of fish was computed using Fulton's coefficient formula. At the end of the experimental period, liver and viscera were removed from fish taken from each experimental tank as three fish/tank for determination of the viscero-somatic index (VSI -eqn 5) and the hepato-somatic index (HSI -eqn 6) (Jobling
1985) and fish tissues (fins and muscles) were preserved in the freezer for carotenoid analysis. Food consumption (\% Bwt/day -eqn 7) and food conversion ratio (FCR -eqn 8) was computed (Ricker, 1979).

\section{Water quality parameters}

Water temperature $\left({ }^{\circ} \mathrm{C}\right)$ was measured daily and the $\mathrm{pH}$ of the water was measured twice a week by using a $\mathrm{pH}$ meter (Eutech pH6, Singapore). Ammonia (range: 0-10 mg/l), nitrite (range: $0-10 \mathrm{mg} / \mathrm{l}$ ) and nitrate (range: 0 $-130 \mathrm{mg} / \mathrm{l})$, of tank water, were measured weekly by using laboratory test kits (ZOOLEK, Poland) The faecal matter voided by the fish in tanks were siphoned out daily by replacing nearly $10 \%$ of the water before feeding the fish in the morning and maintaining the optimum aeration throughout the experimental period.

\section{Stress test}

The salinity stress tests were carried out to evaluate the physiological condition and the quality of the guppy fish (Citarasu et al. 1999). At the end of the 42 days fish from each tank were subjected to a salinity stress challenge. Saline solution $\left(35 \mathrm{gL}^{-1}\right)$ was prepared by dissolving $\mathrm{NaCl}$ in aquarium 
$\%$ Average Daily Gain $(\% A D G)=\frac{(\text { Final } w t-\text { Initial } w t)}{\text { Initial } w t \times\left(t_{2}-t_{1}\right)} \times 100 \ldots$ eqn 1

Where, $\mathrm{t}_{2}-\mathrm{t}_{1}=$ time period in days

$\%$ Specific Growth Rate $(\%$ SGR $)=\frac{\ln (\text { Final } w t)-\ln (\text { Initial } w t)}{\left(t_{2}-t_{1}\right)} \times 100 \ldots$ eqn 2

Where, $\mathrm{t}_{2}-\mathrm{t}_{1}=$ time period in days

$\%$ Survival $=\frac{\text { No.of fish at the end of the experiment }}{\text { Initial No.of the fish }} \times 100 \ldots$ eqn 3

Condition Factor $(K)=\frac{W \times 100}{L^{3}} \ldots$ eqn 4

Where; $W$ is total weight of fish $(\mathrm{g})$ and $L$ is total length of fish $(\mathrm{cm})$

Viserosomatic Index $($ VSI $)=\frac{\text { Visceral weight }(g) \times 100}{\text { Somatic Weight of fish }(g)} \ldots$ eqn 5

Hepatosomatic Index $(H S I)=\frac{\text { Liver weight }(g) \times 100}{\text { Somatic Weight of fish }(g)} \ldots$ eqn 6

Food consumption $(\% B W /$ day $)=\frac{\text { Feed consumed }(g) \times 100}{\text { Weight of fish }(g)} \ldots$ eqn 7

Feed conversion ratio $(F C R)=\frac{\text { Feed consumed }(g) \times 100}{\text { Weight gain }(g)} \ldots$ eqn 8

Cumulative Mortality Index $(C M I)=D X 1+D X 2+D X 3+\cdots+D X n \ldots$ eqn 9

Where: $\mathrm{D}$ is the number of dead individuals at the respective time (in minutes) $\mathrm{X} 1, \mathrm{X} 2, \mathrm{X} 3, . . \mathrm{Xn}$.

Reduction of stress
$=\frac{(\text { CMI value of control })-(\text { CMI value of relevant treatment })}{\text { CMI value of control }} \ldots$ eqn 10

Total carotenoid content (TCC) $(\mu \mathrm{g} g-1)$

$=\frac{\text { Absorption at maximum wave length } \mathrm{x} 10}{0.25 \times \text { sample weight }(\mathrm{g})} \ldots$ eqn 11

Where; $10=$ Dilution factor, $0.25=$ Extinction co-efficient 
water. Six fish per tank were placed in $1 \mathrm{~L}$ of $35 \mathrm{~g} \mathrm{~L}-1$ saline solution and mortality was recorded at $3 \mathrm{~min}$. intervals over a $2 \mathrm{~h}$ period.

The stress resistance of the fish was expressed as the cumulative mortality index (CMI) (eqn 9), which is obtained as the sum of 40 cumulative mortality readings recorded during the observation period (Citarasu et al. 1999). The higher the CMI value, the lower the resistance to the salinity or heat shock (Immanuel et al. 2004).

\section{Reduction of stress}

Using this CMI value, the reduction of stress (eqn 10) was calculated using the following method of Citarasu et al. (1999) and Immanuel et al. (2004).

\section{Determination of total carotenoid content in fish tissues and experimental diets}

Total carotenoid content in the fish tissues and the experimental diets were estimated spectro-photometrically following the method of Torrissen and Navedal (1988). Fins and muscles were removed from three fish/tank and minced thoroughly before conducting carotenoid analysis. Ten $\mathrm{mL}$ of dry acetone and $2 \mathrm{~g}$ of anhydrous $\mathrm{Na}_{2} \mathrm{SO}_{4}$ were added to 1 $\mathrm{g}$ of sample (powdered diet sample or minced fish tissue sample) in a glass centrifuge tube and it was centrifuged at $5000 \mathrm{rpm}$ for 5 minutes. The properly sealed centrifuge tube was stored at $4^{\circ} \mathrm{C}$ in a refrigerator for 3 days and absorption of the supernatant solution was measured at $476 \mathrm{~nm}$ using a spectrophotometer (DR 3900, Hach Company, USA). Total carotenoid content was determined by the following equation (eqn 11).

\section{Statistical analysis}

All the statistical analyses were done using the SPSS statistical package (SPSS 16.0). One way ANOVA was carried out to test the effects of diets on growth parameters feed utilization parameters, stress tolerance, total carotenoid content of fish and experimental diets. Significant $(p<0.05)$ differences among means were followed by a post hoc comparison of means using Duncan multiple range test to distinguish differences among treatment levels. Results are expressed as means \pm SD unless otherwise noted.

\section{RESULTS AND DISCUSSION \\ Growth performance and feed utilization}

This study examined the effect of the addition of dietary probiotic supplements on the growth performances, feed utilization, colouration and stress resistance of guppy fish. All the experimental feeds were isonitrogenous and isolipidic and AQUALACTTM dietary probiotic did not alter the nutritional value of the diet. All the experimental diets were well accepted by guppy fish and no negative effects were observed in fish survival. Survival of Guppy fish was $100 \%$ for all treatments. However, significantly $(p<0.05)$ better growth performance and feed utilization were observed in Guppy fed diets supplemented with probiotics (50PM, 75Pm \& 100PM) compared to that of the fish fed OPM diet in which had no probiotic supplement (Table 3 ). Further, fish fed 75PM diet exhibited significantly $(p<0.05)$ highest body weight $(0.43 \pm 0.01 \mathrm{~g})$ and total length $(3.35 \pm 0.01$ $\mathrm{cm}$ ) at the end of the trial compared to that of fish in all other treatments. Growth indices i.e. ADG, SGR, K, HSI and VSI were significantly higher in all probiotic supplemented (50PM, 75PM, 100PM) groups compared to that of the control group (0PM). Although the administration of probiotics in fish feed is first used as an alternative to antibiotics and vaccines usage of aquaculture, it was later observed that dietary additive of probiotics improves growth performance and feed utilization of fish (Merrifield et al. 2010). The addition of probiotics to the diets in the present study significantly influenced the growth performance of guppy and similar results were reported by Ghosh et al. (2008) where diets containing probiotic supplements showed significant improvement in weight gain in Platy fish. The nutrient levels of experimental diets were comparable with the required levels of nutrients (protein and lipid) for the growth of guppy (Shim and Chua, 1986; NRC, 1993).

The inclusion of dietary probiotic supplement did not influence the feed intake (\% BWt/day) 
of fish in the present study. Mean daily food consumption (\% BWt/day) of guppy fish was around $8 \%$ which was not significantly ( $p>0.05)$ different among the treatments. Food conversion ratio (FCR) of $75 \mathrm{PM}$ treatment $(2.51 \pm 0.01)$ was significantly $(p<0.05)$ better than that of the other treatments and 50PM and 100PM treatments also showed better FCR values compared to control (0PM) treatment. The low FCR values (better FCR values) observed in probiotic supplemented diets suggested that addition of probiotics improved feed utilization of guppy and similar observations were reported by Dharmaraj and Devendran (2010). Some other studies also pointed out that dietary probiotic supplementation improved growth performance and food conversion ratio of fish. Manoppo et al (2019) reported that tilapia fed probiotic supplemented diets showed better (lower) FCR values (1.12 1.29) compared to fish fed the control diet (FCR- 2.08) without probiotics supplementation. He et al (2011) studied the effects of dietary probiotic supplementation of Bacillus subtilis (Calsporin) on growth and feed performance of Koi carp and stated that weight gain and feed conversion ratio were significantly improved when fish fed dietary probiotics. Fish fed control diet without probiotic showed higher FCR $(1.41+0.06)$ compared to fish fed calsporin supplemented diet which showed lower (better) FCR (1.31 + 0.04). Oscar (Astronotus occelatus) fingerlings fed $0.15 \mathrm{~g} / \mathrm{Kg}$ of dietary protexin (probiotic) supplemented feed for two months period showed significantly better FCR value of 1.13 compared to FCR values for fish in control treatment with no probiotics (1.23), $\mathrm{T} 1$ with $0.5 \mathrm{~g} / \mathrm{kg}$ probiotics (1.21) and T2 with $1.0 \mathrm{~g} / \mathrm{kg}$ probiotics (1.23) (Firouzbakhsh et al. 2011).

Previous studies suggested that probiotics beneficially affected the digestive processes of fish and prawns because probiotic strains synthesize extracellular enzymes such as proteases, amylases, and lipases and also provide growth factors such as vitamins, fatty acids, and amino acids (Balcazar et al. 2006). Therefore, nutrients are absorbed more efficiently when the feed is supplemented with probiotics (Haroun et al. 2006). Incorporating B. subtilis in the diets of Guppy and Swordtail fish resulted increase in the length and weight of the ornamental fishes as well as the specific activity of proteases and amylases in the digestive tract (Ghosh et al. 2008). It has been reported that the commercial probiotic Biogen supplemented diets significantly influenced the growth and feed performances of African catfish (ELHaroun 2007). Bomba et al., (2002) have been suggested that probiotics influence digestive processes by enhancing beneficial gut microfloral populations, this intern enhances and absorption of food and feed utilization.

After reaching the optimum inclusion level of probiotics, the growth performance of fish would not be increased anymore even though by increasing the probiotic level (Garg 2015). For example, Catla catla fed diets with gut isolated probiotic Bacillus coagulans (Bhatnagar and Lamba, 2015), P. monodon fed diets with Bacillus sp. as probiotics (Rengpipat et al. 1998) and Labeo rohita fingerlings fed diets with $B$. circulans as probiotics (Ghosh et al. 2003) showed higher growth at the optimum inclusion level. Similarly, Lara-Flores et al. (2003) reported that probiotics $S$. faecium and L. acidophilus $(0.1 \%)$, and the yeast $S$. cerevisiae $(0.1 \%)$ incorporated diets had improved the growth performance of Nile tilapia (Oreochromis niloticus). In the present study, the $75 \mathrm{Pm}$ diet which had $0.75 \%$ of probiotic supplement exhibited the best growth and feed performances among the tested diets and showed better growth and feed performances compared to fish in 100PM treatment in which, the diet had a higher inclusion level of probiotic.

The present study also demonstrated that the supplement of probiotics positively influenced the HSI and VSI of Guppy and similar results were reported in earlier studies (Garg, 2015). It may attribute to enzymatic activities of the probiotic bacteria in the intestine of the fish and the increment of the HSI and VSI are attributed to the higher growth rate of the fish (Ramos et al. 2015). In biomedical research, 
the VSI index is used as an important indicator to assess animal functional status and the development process (Jobling 1985). When the food is available in optimum amount and conditions are favourable it causes to increase in the HSI and VSI values. As the liver is a vital organ in the body, it performs various physiological functions such as converting excess sugar into glycogen, detoxifying the toxic substances, and also destroying old red blood cells. The HSI indicates the condition of the liver and body and also indicates on status of energy reserve in fish (Austreng 1978).

\section{Total carotenoid content}

All experimental diets exhibited similar levels of dietary carotenoid content which was around $3.2 \mu \mathrm{gg}^{-1}$. However, the total carotenoid content of the skin and muscles of fish in all three probiotic supplement groups were significantly higher $\left(6.31-6.80 \mu \mathrm{gg}^{-1}\right)$ compared to that $\left(4.54 \pm 0.11 \mu \mathrm{gg}^{-1}\right)$ of fish fed the control diet (OPM) (Table 4). Although no significant differences in carotenoid content in diets were observed, guppy fed probiotic supplemented diets had significantly higher carotenoid content in their skin and muscles than that of fish in the OPM control group. Further, the guppy fish fed probiotic supplemented diets showed bright orange colour in their dorsal fins and fish the fed control diet did not show that colouration (data not shown). It has been reported that the tissue pigmentation of Puntius conchonius fed with Rhodococcus sp. showed a greater colouration compared to the control group (Vianey et al. 2016). This is due to the production of carotenoid pigments by bacteria (Vianey et al. 2016), which could easily be integrated into the metabolism of fish. Therefore, the use of probiotic bacteria in aquaculture is important because it not only improves the growth and survival of fish, but also enhance the coloration by increasing tissue pigments. The coloration is one of the

Table 3: Growth and feed performances of Poecilia reticulata fed with experimental diets supplemented with different levels of probiotic mixture for 42 days of the experimental period. (0PM- no probiotic; 50PM- 0.5\% probiotic mix; 75PM- 0.75\% probiotic mix; 100PM- 1\% probiotic mix).

\begin{tabular}{lllll}
\hline Parameter & \multicolumn{4}{c}{ Experimental diets } \\
\cline { 2 - 5 } & $\mathbf{0 P M}$ & $\mathbf{5 0 P M}$ & $\mathbf{7 5 P M}$ & $\mathbf{1 0 0 P M}$ \\
\hline Initial body weight $(\mathrm{g})$ & $0.11 \pm 0.01^{\mathrm{a}}$ & $0.11 \pm 0.01^{\mathrm{a}}$ & $0.11 \pm 0.01^{\mathrm{a}}$ & $0.11 \pm 0.01^{\mathrm{a}}$ \\
Initial total length $(\mathrm{cm})$ & $2.27 \pm 0.04^{\mathrm{a}}$ & $2.22 \pm 0.01^{\mathrm{a}}$ & $2.21 \pm .001^{\mathrm{a}}$ & $2.22 \pm 0.04^{\mathrm{a}}$ \\
Final body weight $(\mathrm{g})$ & $0.35 \pm .0 .01^{\mathrm{a}}$ & $0.40 \pm 0.01^{\mathrm{b}}$ & $0.43 \pm 0.01^{\mathrm{c}}$ & $0.40 \pm 0.01^{\mathrm{b}}$ \\
Final total length $(\mathrm{cm})$ & $3.16 \pm 0.01^{\mathrm{a}}$ & $3.25 \pm 0.02^{\mathrm{b}}$ & $3.35 \pm 0.01^{\mathrm{c}}$ & $3.25 \pm 0.02^{\mathrm{b}}$ \\
\% SGR & $2.64 \pm 0.13^{\mathrm{a}}$ & $3.02 \pm 0.04^{\mathrm{b}}$ & $3.30 \pm 0.15^{\mathrm{c}}$ & $3.13 \pm 0.06^{\mathrm{bc}}$ \\
$\%$ ADG & $4.85 \pm 0.40^{\mathrm{a}}$ & $6.10 \pm 0.14^{\mathrm{b}}$ & $7.15 \pm 0.59^{\mathrm{c}}$ & $6.47 \pm 0.22^{\mathrm{bc}}$ \\
K & $1.11 \pm 0.01^{\mathrm{a}}$ & $1.16 \pm 0.01^{\mathrm{b}}$ & $1.16 \pm 0.01^{\mathrm{b}}$ & $1.16 \pm 0.02^{\mathrm{b}}$ \\
HSI & $0.38 \pm 0.03^{\mathrm{a}}$ & $0.61 \pm 0.01^{\mathrm{b}}$ & $0.63 \pm 0.03^{\mathrm{b}}$ & $0.62 \pm 0.02^{\mathrm{b}}$ \\
VSI & $8.39 \pm 0.34^{\mathrm{a}}$ & $12.48 \pm 0.34^{\mathrm{b}}$ & $14.59 \pm 0.61^{\mathrm{c}}$ & $14.20 \pm 0.18^{\mathrm{c}}$ \\
FCR & $2.77 \pm 0.02^{\mathrm{a}}$ & $2.69 \pm .0 .04^{\mathrm{b}}$ & $2.51 \pm 0.01^{\mathrm{c}}$ & $2.66 \pm 0.04^{\mathrm{b}}$ \\
$\%$ Survival & $100^{\mathrm{a}}$ & $100^{\mathrm{a}}$ & $100^{\mathrm{a}}$ & $100^{\mathrm{a}}$ \\
Food consumption $(\%$ & $8.24 \pm 0.15^{\mathrm{a}}$ & $8.35 \pm 0.17^{\mathrm{a}}$ & $8.51 \pm 0.36^{\mathrm{a}}$ & $8.56 \pm 0.33^{\mathrm{a}}$ \\
BW/ Day) & & & & \\
\hline
\end{tabular}

Note: Each value is a mean of three replicates. Means within each row followed by different letters are significantly different $(\mathrm{P}>0.05)$. 
Table 4: Mean ( \pm SD) Carotenoid content of fin and muscle tissue of guppy and experimental diets. (0PM- no probiotic; 50PM- 0.5\% probiotic mix; 75PM- 0.75\% probiotic mix; 100PM- 1\% probiotic mix).

\begin{tabular}{lcccc}
\hline Parameter & \multicolumn{4}{c}{ Treatments } \\
& 0PM & 50PM & 75PM & 100PM \\
\hline Experimental diets $\left(\mu \mathrm{g} \mathrm{g}^{-1}\right)$ & $3.23 \pm 0.08^{\mathrm{a}}$ & $3.24 \pm 0.11^{\mathrm{a}}$ & $3.23 \pm 0.06^{\mathrm{a}}$ & $3.21 \pm 0.09^{\mathrm{a}}$ \\
Fin and muscle tissues $\left(\mu \mathrm{g} \mathrm{g}^{-1}\right)$ & $4.54 \pm 0.11^{\mathrm{a}}$ & $6.31 \pm 0.20^{\mathrm{b}}$ & $6.80 \pm 0.53^{\mathrm{b}}$ & $6.68 \pm 0.36^{\mathrm{b}}$ \\
\hline
\end{tabular}

Note: Each value is a mean of three replicates. Means within each row followed by different letters are significantly different $(\mathrm{P}>0.05)$.

significant criteria in ornamental trade industry. Fish are unable to synthesize their own coloring pigments and depend on the pigment supplement in diet that are very expensive if they are commercially acquire (Gouveia, 2003). In commercial aquaculture practices, the coloring agents which are synthesized by algae, plants and microorganisms are incorporated in the diet. Therefore the inclusion of probiotic bacteria into diets is a more economical way to enhance the coloration of fish (Vianey et al. 2016).

\section{Salinity stress test}

Salinity stress tests could be an effective tool for evaluating the stress resistance of the fish. The test was effective in distinguishing the stress resistance levels of fish fed different diets (Hernandez et al. 2010). After exposing guppy to salinity stress in $35 \mathrm{ppt}$, all fish fed on control diet died within 15 minutes while fish fed on probiotic diets showed a higher stress tolerance up to 40 minutes (Figure 1). Fish fed probiotic supplemented diets showed significantly $(p>0.05)$ better stress tolerance to $35 \mathrm{~g} \mathrm{~L}^{-1}$ salinity stress and Cumulative mortality index (CMI) were lower (CMI of 173-186) than that of the control group (OPM -CMI of 240)). In addition, there were no significant differences in the CMI and \% reduction of stress of fish among the 50PM, 75PM and 100PM diets (Table 5). The present observations revealed that feeding the guppy fish with a probiotic supplemented diet would effectively enhance their stress resistance. Probiotics have been used as dietary supplements to enhance the health and nutritional performance of a range of fish species (Gurov et al. 2011). Improvements in growth, feed utilization, lipid metabolism, physiological activity, and stress response and disease resistance of fish have been reported (Mustafa et al. 1994). Tarnecki et al, (2019) reported that the use of a Bacillus probiotic improves survival and transport stress resistance in common snook.

The improvement in growth and salinity stress resistance may be related to the improvement in the intestinal microbial flora balance as reported by Fuller (1989). Lara-Flores et al. (2003) also observed a similar trend where the addition of $0.1 \%$ probiotics in diets for tilapia fry improved growth and apparent protein digestibility and mitigated the effects of stress factors. In practical terms, this means that probiotics can be used to utilize the feed efficiently by improving FCR, which could result in production cost reductions, because probiotic supplemented diets showed higher feed consumption rate with better FCR, faster growth rate, enhances the body's ability to resist stress and the attacks of pathogens (Garg 2015; Gomez-Gil et al. 2000).

\section{Water quality parameters}

Maintaining optimum water quality is one of the key factors in successful aquaculture practices. Temperature, $\mathrm{pH}$, ammonia, nitrite and nitrate levels of tank water recorded in the present study were within the appropriate range for Guppy fish (Maddy 2009). Temperature, $\mathrm{pH}$ and total ammonia nitrogen (TAN) concentrations in the rearing tanks were not significantly $(\mathrm{p}<0.05)$ different among the treatments (Table 6). All the experimental tanks were well aerated and 
Table 5: Cumulative mortality index (CMI) and percentage reduction of stress (\% ROS) in Poecilia reticulata fed with different diets and exposed to $35 \mathrm{ppt}$ salinity stress. (0PM- 0\% probiotic mix; 50PM- 0.5\% probiotic mix; 75PM- 0.75\% probiotic mix; 100PM- 1\% probiotic mix)

\begin{tabular}{lllllll}
\hline \multirow{2}{*}{$\begin{array}{l}\text { Treat- } \\
\text { ment }\end{array}$} & \multicolumn{2}{l}{ After 15 minutes } & \multicolumn{2}{l}{ After 30 minutes } & \multicolumn{2}{l}{ After 40 minutes } \\
\cline { 2 - 7 } & CMI & \% ROS & CMI & \% ROS & CMI & \% ROS \\
\hline $0 \mathrm{PM}$ & $70.0 \pm 8.66^{\mathrm{a}}$ & 0.0 & $180.0 \pm 0.0^{\mathrm{a}}$ & 0.0 & $240.0 \pm 0.0^{\mathrm{a}}$ & 0.0 \\
$50 \mathrm{PM}$ & $10.0 \pm 8.66^{\mathrm{b}}$ & 85.71 & $80.0 \pm 17.32^{\mathrm{b}}$ & 55.56 & $186.67 \pm 23.09^{\mathrm{b}}$ & 22.22 \\
$75 \mathrm{PM}$ & $5.0 \pm 8.66^{\mathrm{b}}$ & 92.86 & $80.0 \pm 17.32^{\mathrm{b}}$ & 55.56 & $186.67 \pm 23.09^{\mathrm{b}}$ & 22.22 \\
$100 \mathrm{PM}$ & $5.0 \pm 8.66^{\mathrm{b}}$ & 92.86 & $70.0 \pm 17.32^{\mathrm{b}}$ & 55.56 & $173.33 \pm 23.09^{\mathrm{b}}$ & 27.78 \\
\hline
\end{tabular}

Note: Each value is a mean of three replicates. Means within each column followed by different letters are significantly different $(P>0.05)$.

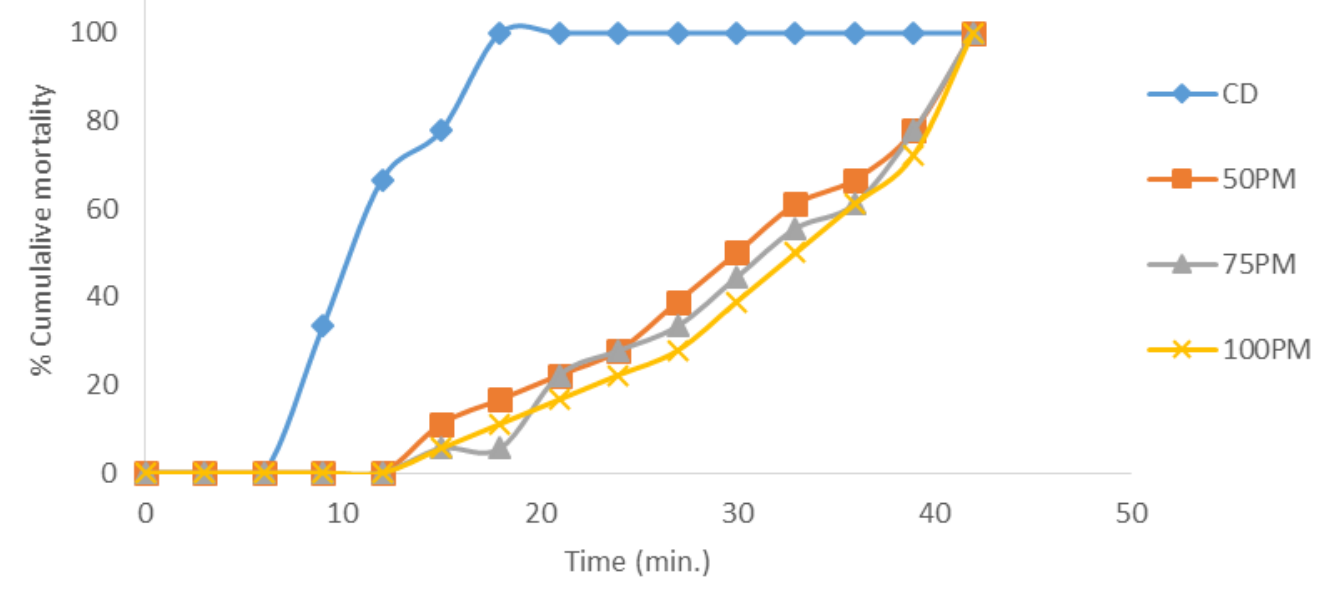

Figure 1: Mean $( \pm$ SD) percentage cumulative mortality of Poecilia reticulata fed with different experimental diets exposed to 35 ppt salinity stress after 42 days of experiment period. (0PM- 0\% probiotic mix; 50PM- 0.5\% probiotic mix; 75PM- 0.75\% probiotic mix; 100PM- 1\% probiotic mix)

faecal matters were siphoned daily throughout the experimental period of 42 days. Water temperature and $\mathrm{pH}$ were ranged between 27.84 ${ }^{\circ} \mathrm{C}-27.95{ }^{\circ} \mathrm{C}$ and 7.41-7.47 in tank waters respectively. TAN levels were near 0 levels in all tanks. Ammonia (TAN), nitrite and nitrate levels were in the acceptable range. Water $\mathrm{pH}$ should be between $6.8-7.4$ and the total ammonia nitrogen (TAN) should be below $0.34 \mathrm{mg} / \mathrm{L}$ for better growth of guppy (Da 2012).

\section{CONCLUSION}

Results of the present study indicate that use of probiotics can be used to enhance growth, nutrient utilization, carotenoid content of tissues and higher salinity stress tolerance guppy fish without any negative effects on the survival rate. Consequently, significantly higher growth performance was observed in fish fed on $75 \mathrm{PM}(0.75 \%$ probiotic mix $)$ feed. It might indicate that when the dietary levels of probiotics increased, growth performance would be increased up to a certain level. It can 
Table 6: Water quality parameters (Mean \pm SD) during 42 days of rearing period for Guppy fed experimental diets (0PM- 0\% probiotic mix; 50PM- 0.5\% probiotic mix; 75PM- 0.75\% probiotic mix; 100PM- $1 \%$ probiotic mix)

\begin{tabular}{lllll}
\hline Parameter & \multicolumn{4}{c}{ Experimental diets } \\
\cline { 2 - 5 } & $\mathbf{0 P M}$ & $\mathbf{5 0 P M}$ & $\mathbf{7 5 P M}$ & $\mathbf{1 0 0 P M}$ \\
\hline Temperature $\left({ }^{\circ} \mathrm{C}\right)$ & $27.93 \pm 0.02$ & $27.85 \pm 0.01$ & $27.86 \pm 0.01$ & $27.92 \pm 0.02$ \\
$\mathrm{pH}$ & $7.46 \pm 0.01$ & $7.42 \pm 0.01$ & $7.46 \pm 0.01$ & $7.44 \pm 0.01$ \\
Ammonia $(\mathrm{mg} / \mathrm{L})$ & 0 & 0 & 0 & 0 \\
Nitrite $(\mathrm{mg} /$ & $0.10 \pm 0.02$ & $0.10 \pm 0$ & $0.11 \pm 0.03$ & $0.10 \pm 0.02$ \\
Nitrate $(\mathrm{mg} / \mathrm{L})$ & $15 \pm 0.05$ & $15 \pm 0.06$ & $15 \pm 0.06$ & $15 \pm 0.05$ \\
\hline
\end{tabular}

be concluded that dietary supplementation of $0.75 \%$ of AQUALACTTM could be used for optimum growth performance of guppy fish.

\section{AUTHOR CONTRIBUTION}

RK conceptualized and designed the study. ST performed the experiments. RK and RS supervised the research work. ST and RK analyzed and interpret the data and contributed in original draft and RK critically revised and edited the manuscript.

\section{References}

Anuar NS, Omar NS, Noordiyana MN snd Sharifah NE 2017 Effect of commercial probiotics on the survival and growth performance of goldfish Carassius auratus. Aquaculture, Aquarium, Conservation and Legislation, 10:1663-1670.

AOAC 1990 Official methods of analysis. 15th edn. Association of Official Analytical Chemists, Arlington, Virginia, USA. 1094 pp.

Austreng E 1978 Digestibility determination in fish using chromic oxide marking and analysis of contents from different segments of the gastrointestinal tract. Aquaculture 13:265-272. https:// doi.org/10.1016/0044-8486(78)90008-X.

Balcazar J L, Blas I D, Ruiz-Z I, Cunningham D, Vendrell D and Muzquiz JL 2006 The role of probiotics in aquaculture. Veterinary Microbiology, 114:173-186.

Bhatnagar A and Lamba R 2015 Antimicrobial ability and growth promoting effects of feed supplemented with probiotic bacterium isolated from gut microflora of Cirrhinus mrigala. Journal of
Integrative Agriculture, 14:583-592. https://doi.org/10.1016/S2095-3119.

Bomba A, Nemcoal R, Gancarc koval S, Herich R, Guba P and Mudron oval D 2002 Improvement of the probiotic effect of microorganisms by their combination with maltodextrins, fructooligosaccharides and polyunsaturated fatty acids. British Journal of Nutrition, 88:95-99. doi: 10.1079/BJN2002634.

Citarasu T, Immanuel G and Marian MP 1999 Effect of feeding Artemia enriched with stresstol and cod liver oil on growth and stress resistance in the Indian white shrimp Penaeus indicus postlarvae. Asian Fisheries Science, 12:65-76.

Cruz PM, Iba'nez A L, Hermosillo OAM and Saad HCR 2012 Review Article: Use of Probiotics in Aquaculture, ISRN Microbiology, 12:1-13, doi:10.5402/2012/91684.

Da CT 2012 Evaluation of locally available feed resources for striped cat fish (Pangasianodon hypophthalmus). Doctoral Thesis, Swedish University of agricultural Sciences, Uppsala, Sweden. p. 78.

Dharmaraj S and Kandasamy D 2010 Evaluation of Streptomyces as a Probiotic Feed for the Growth of Ornamental Fish Xiphophorus helleri. Growth, Food Technology and Biotechnolgy, 48:497504.

Doan HV, Hoseinifar SH, Ringø E, Esteban MA, Dadar M, Dawood MA and Faggio C 2020 Host-associated probiotics: a key factor in sustainable aquaculture. Reviews in fisheries science and aquaculture, 28:16 -42 . https:// doi.org/10.1080/23308249.2019.1643288 
EDB 2021 Aquarium fish. Retrieved 6 July 2021 from https:// www.srilankabusiness.com/ aquariumfish/overview.html

El-Haroun ER 2007 Improved growth rate and feed utilization in farmed African catfish Clarias gariepinus (Burchell 1822) through a growth promoter Biogen $\mathbb{}$ supplementation. Journal of Fisheries and Aquatic Sciences, 2:319-327. doi: 10.3923/jfas.2007.319.327

Firouzbakhsh F, Noori F, Khalesi MK and Jani-Khalili K 2011 Effects of a probiotic, protexin, on the growth performance and hematological parameters in the Oscar (Astronotus ocellatus) fingerlings. Fish Physiology and Biochemistry, 37:833-842

Fuller R 1989 Probiotics in man and animal, Journal of Applied Bacteriology 66:365378 . https://doi.org/10.1111/j.13652672.1989.tb05105.x

Garg SK 2015 Effect of dietary probiotic mix (SPILAC) on growth performance and nutritive physiology of Nile tilapia, Oreochromis niloticus (Linn.) under laboratory conditions. International Journal of Fisheries and Aquatic Studies, 3:440-446

Ghosh K, Sen SK and Ray AK 2003 Supplementation of an isolated fish gut bacterium, Bacillus circulans, in formulated diets for rohu, Labeo rohita, fingerlings, The Israeli Journal of Aquaculture - Bamidgeh, 55:13-21.

Ghosh S, Sinha A and Sahu C 2008 Dietary probiotic supplementation in growth and health of live $\square$ bearing ornamental fishes. Aquaculture Nutrition, 14:289-299. https://doi.org/10.1111/j.13652095.2007.00529.x

Gomez-Gil B, Roque A and Turnbull JF 2000 The use and selection of probiotic bacteria for use in the culture of larval aquatic organisms. Aquaculture 191:259-270. https://doi.org/10.1016/S0044-8486 00431-2

Gouveia L 2003 Colouring ornamental fish (Cyprinus carpio and Carassius auratus) with micro algal biomass. Aquaculture Nutrition, 9:123-129

Gurov AV, Battisti A and Roques A 2011 Invertebrate response to the fragmentation of boreal forests: edge effects. In Proceedings of the international conference on Boreal forests in a changing world: challenges and needs for actions, Sukachev Institute of Forest SB RAS. Krasnoyarsk, Russia. pp. 124-129.

Haroun E, Goda A and Kabir M 2006 Effect of dietary probiotic Biogen supplementation as a growth promoter on growth performance and feed utilization of Nile tilapia Oreochromis niloticus (L.). Aquaculture Research, 37:1473-1480

He S, Liu W, Zhou Z, Mao W, Ren P 2011 Evaluation of probiotic strain Bacillus subtilis C-3102 as a feed supplement for koi carp (Cyprinus carpio). Journal of Aquaculture Research and Development S1:005. doi:10.4172/2155-9546.S1-005

Hernandez LHH, Barrera TC, Mejia JC, Mejia GC, Del Carmen M, Dosta M, De Lara, Andrade R and Sotres JAM 2010 Effects of the commercial probiotic Lactobacillus casei on the growth, protein content of skin mucus and stress resistance of juveniles of the Porthole livebearer Poecilopsis gracilis (Poecilidae). Aquaculture nutrition, 16:407-411. https:// doi.org/10.1111/j.1365-2095.2009.00679.x

Immanuel G, Vincybai VC, Sivaram V, Palavesam A and Marian MP 2004 Effect of butanolic extracts from terrestrial herbs and seaweeds on the survival, growth and pathogen (Vibrio parahaemolyticus) load on shrimp Penaeus indicus juveniles. Aquaculture, 236:53-65. https:// doi.org/10.1016/j.aquaculture.2003.11.033

Jobling M 1985 Physiological and social constraints on growth of fish with special reference to Arctic charr, Salvelinus alpinus L. Aquaculture, 44:83-90. https:// doi.org/10.1016/0044-8486(85)90011-0

Lara-Flores M, Olvera-Novoa MA, GuzmánMéndez BE and López-Madrid W 2003 Use of the bacteria Streptococcus faecium and Lactobacillus acidophilus, and the yeast Saccharomyces cerevisiae as growth promoters in Nile tilapia (Oreochromis niloticus). Aquaculture, 216:193-201. https://doi.org/10.1016/S0044-8486(02) 00277-6

Maddy H 2009 Back to the basics: Breeding guppies. Online Tropical Fish Magazine 
July 2019, viewed 08 November 2015, $<$ https://www.thmagazine.com/details/ articles/back-to-the-basics-breedingguppies.

Manoppo H, Tumbol RA, Sinjal HJ and Sumaraw J 2019 Growth and feed efficiency enhancement by probiotic originating from intestine of carp, Cyprinus carpio. Aquaculture, Aquarium, Conservation and Legislation, 12:21882194

Merrifield DL, Dimitroglou A, Foey A, Davies SJ, Baker RT, Bøgwald J, Castex $M$ and Ringø E 2010 The current status and future focus of probiotic and prebiotic applications for salmonids. Aquaculture, 302:1-18. https://doi.org/10.1016/ j.aquaculture.2010.02.007

Mustafa MG, Takeda TA, Umino T, Wakamatsu S and Nakagawa H 1994 Effects of Ascophyllum and Spirulina meal as feed additives on growth performance and feed utilization of red sea bream, Pagrus major. Journal of the Faculty of Applied Biological Science, Hiroshima University 33:125-132.

Nikoskelainen S, Ouwehand A, Salminen S and Bylund G 2001 Protection of rainbow trout (Oncorhynchus mykiss) from furunculosis by Lactobacillus rhamnosus. Aquaculture, 198:.229-236. https:// doi.org/10.1016/S0044-8486(01)00593-2

Picchietti S, Mazzini M, Taddei AR, Renna R, Fausto AM, Mulero V, Carnevali O, Cresci A and Abelli L 2007 Effects of administration of probiotic strains on GALT of larval gilthead seabream: immunohistochemical and ultrastructural studies. Fish and Shellfish Immunology 22:57-67. https://doi.org/10.1016/ j.fsi.2006.03.009

Ramos MA, Gonçalves JFM, Batista S, Costas B, Pires MA, Rema P and Ozório ROA 2015 Growth, immune responses and intestinal morphology of rainbow trout (Oncorhynchus mykiss) supplemented with commercial probiotics. Fish and shellfish immunology, 45:1926.https://doi.org/10.1016/ j.fsi.2015.04.001

Rengpipat S, Phianphak W, Piyatiratitivorakul $\mathrm{S}$ and Menasveta P 1998 Effect of a probiotic bacterium on black tiger shrimp Penaeus monodon survival and growth. Aquaculture, 167:301-313 https:// doi.org/10.1016/S0044-8486(98)00305-6

Ricker WE 1979 Growth rates and models. In: WS Hoar, DJ Randall and JR Brett (eds) Fish Physiology bioenergetics and growth, Vol. VIII, Academic Press, New York, pp. 677-743. https://doi.org/10.1016/S15465098(08)60034-5

Shim, K.F and Chua, YL 1986 Some studies on the protein requirement of the guppy, Poecilia reticulata (Peters). Journal of Aquariculture and Aquatic Science, 4:7984.

Tarnecki AM Wafapoor A, Phillips RH, and Rhody NR 2019 Benefts of a Bacillus probiotic to larval fish survival and transport stress resistance. Scientific Reports 9:4892, doi.org/10.1038/s41598019-39316-w

Torrissen OJ and Naevdal G 1988 Pigmentation of salmonids- variation in flesh carotenoids of Atlantic salmon. Aquaculture, 68: 305-310. https:// doi.org/10.1016/0044-8486(88)90244-X

Verschuere L, Rombaut G, Sorgeloos P and Verstraete W 2000 Probiotic bacteria as biological control agents in aquaculture. Microbiology and Molecular Biology Reviews, 64:655-671. https:// doi.org/10.1128/MMBR.64.4.655671.2000

Vianey PGC, del Carmen MDM, Tórrez JAR, Cervantes JAO and Mejía JC 2016 Rhodococcus sp. as probiotic bacteria for increase the survival, growth and coloration of fish Puntius conchonius. Scientific Journal of Animal Science, 5:370-375. https://doi: 10.14196/ sjas.v5i12.2341 